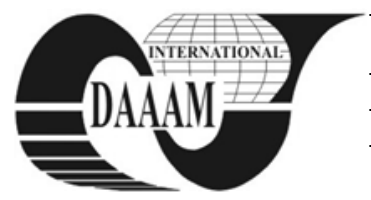

Annals of DAAAM for 2011 \& Proceedings of the 22nd International DAAAM Symposium, Volume 22, No. 1, ISSN 1726-9679 ISBN 978-3-901509-83-4, Editor B. Katalinic, Published by DAAAM International, Vienna, Austria, EU, 2011 Make Harmony between Technology and Nature, and Your Mind will Fly Free as a Bird

\title{
APPLICATION OF SEQUENCE DIAGRAM WITHIN TOOL CHANGE DURING MACHINING
}

\author{
DANISOVA, N[ina]; SEBENOVA, S[ilvia] \& VELISEK, K[arol]
}

\begin{abstract}
In this contribution is presented application of sequence diagram within tool change during machining at the intelligent manufacturing and assembly cell. Intelligent manufacturing and assembly cell is situated at the Institute of Production Systems and Applied Mechanics. The complex design of production sequences at the intelligent manufacturing and assembly cell is realized on the basis of sequential diagrams and outgoing from knowledge about intelligent manufacturing systems. Intelligent manufacturing systems as systems of new generation are gradually loaded in to the mechanical production, when they are removeing human operation out of production process and they also short production times.
\end{abstract}

Key words: system, production, intelligent manufacturing, cell

\section{INTRODUCTION}

Flexible manufacturing - assembly cell is placed at the Institute of Production Systems and Applied Mechanics (Fig.1.).

Flexible manufacturing cell is realized from these subsystems:

1. Industrial robot with Cartesian workplace

2. Shelf storage system

Following to the conclusions and knowledge, which are coming from intelligent systems studies, were in the flexible manufacturing cell designed special added sensor units for each device (Kostal \& Mudrikova 2008).

That means that every device will have its own sensor units, which will be used for processing of primal information. Such information ensures communication between single devices and control system. Before single sensor units specification, there was needed to specify requirements, which will be given to the designed intelligent manufacturing and assembly cell. (Kusiak 2006).

Designed intelligent cell have to be able to react on various situations which are coming during the manufacturing process (Kusiak \& Salustri 2010).

During the design of intelligent cell, there was very important to conserve two basic subsystems, such as was during flexible manufacturing cell design. At this contribution is resolved requirement of sensorial equipment at the cell workplace: "React to tools change“. Cartesian robot must to operate different works. One of the main works is tool change during machining. In the (Fig.2.) is possible to see tool spindle.

Five working phases is integrated in the flexible manufacturing cell (Majerik \& Bajcik 2008).

1. Storage (storage of semi-products, final products before its expedition),

2. Transport and manipulation (transport and manipulation with semi products and final products),

3. Manufacture (manufacturing of single semi products to the final product),

4. Assembly (assembly of single parts in to the one final product),

5. Expedition.

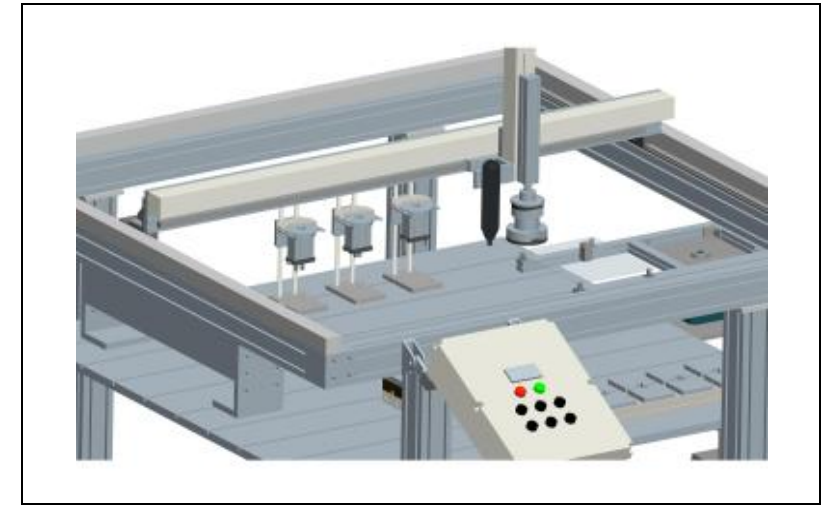

Fig. 1. Flexible manufacturing - assembly cell

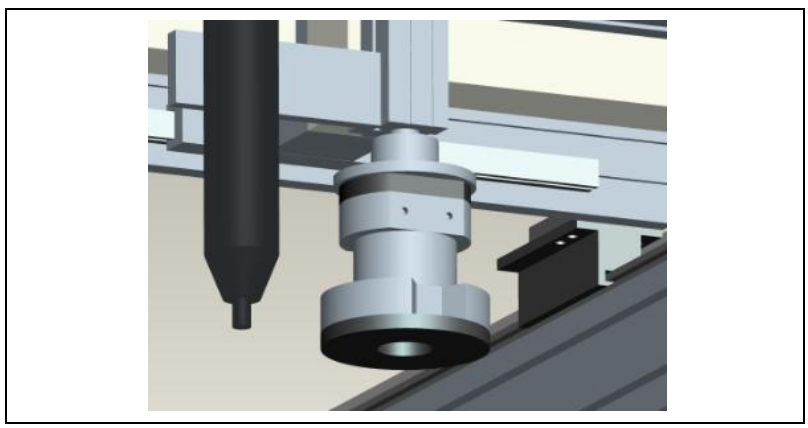

Fig. 2. Tool spindle at the intelligent manufacturing - assembly cell

In the (Fig.3.) is intelligent cell workplace - axis Z.

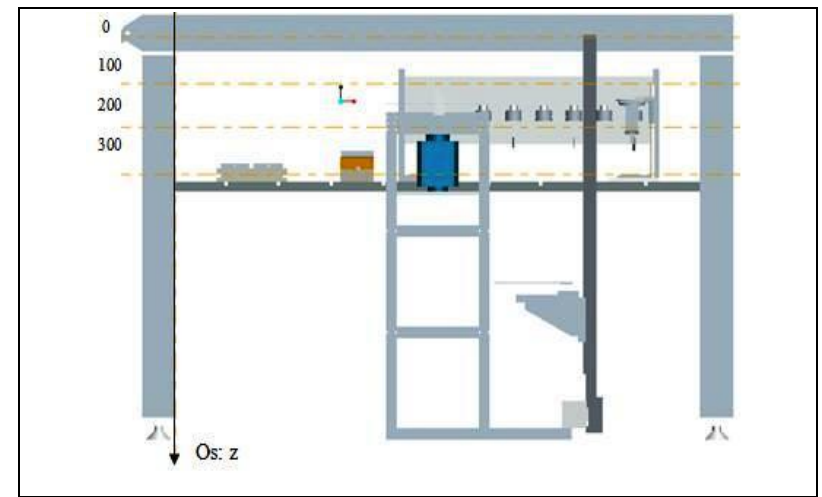

Fig. 3. Intelligent cell workplace

\section{METHODOLOGY OF COMMUNICATION WAYS BETWEEN SINGLE DEVICES OF IMC}

Before design of sensor equipment of all system subsystems, there was also important to solve writing kind of single stays and movements connected with parts. These stays of parts have to be created during running production process in 
the intelligent manufacturing cell (Mudrikova \& Charbulova 2010).

Proper writing methodology was created, which would be able to define the communication ways between single devices during running production process. Sensor equipment can be designed following to the writing of communication ways between single devices. At the beginning there were two kinds of methodology:

- Methodology which is using evolution diagrams and algorithms.

- Methodology of writing which is using rules of sequential diagrams (Fig. 4.).

- Sequence diagram, it is a new writing form, which is usually used are writing form for programming in the language UML. These diagrams are used for description of objects stays. Sequential diagrams are used for showing, how are single objects communicating to each other in the time (Katalinič 2007). Methodology of sequential diagrams was chosen as a proper methodology for communication writing between single devices operated in the intelligent manufacturing cell. Only synchronous messages can be found in the designed intelligent manufacturing cell. That means, there will not be any other operation created without backward signal in the control unit (Katalinič 2002).

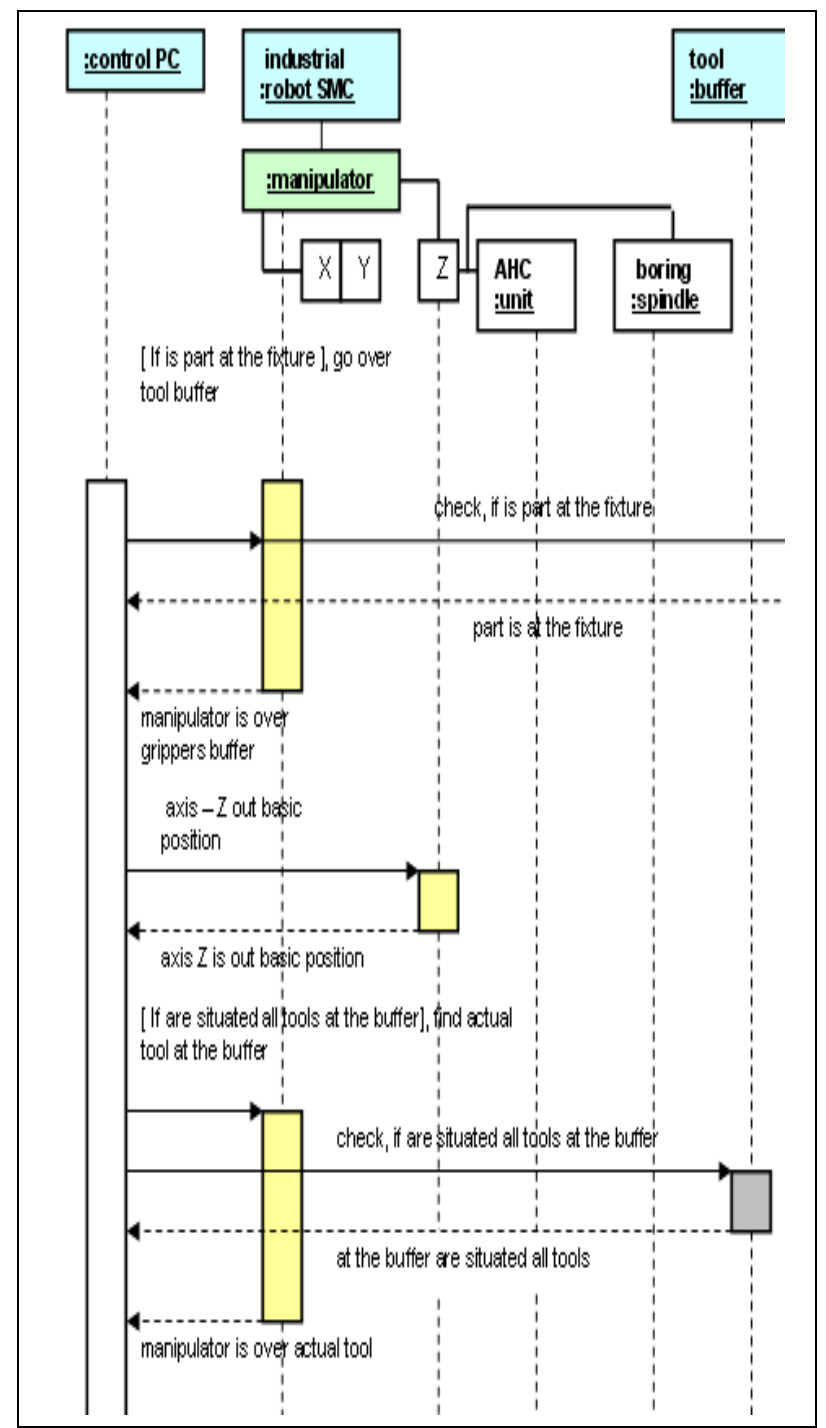

Fig. 4. Sequence diagram of automated tool change during machining

In the (Fig. 5.) is workplace at the intelligent manufacturing cell - axis $\mathrm{X}, \mathrm{Y}, \mathrm{Z}$.

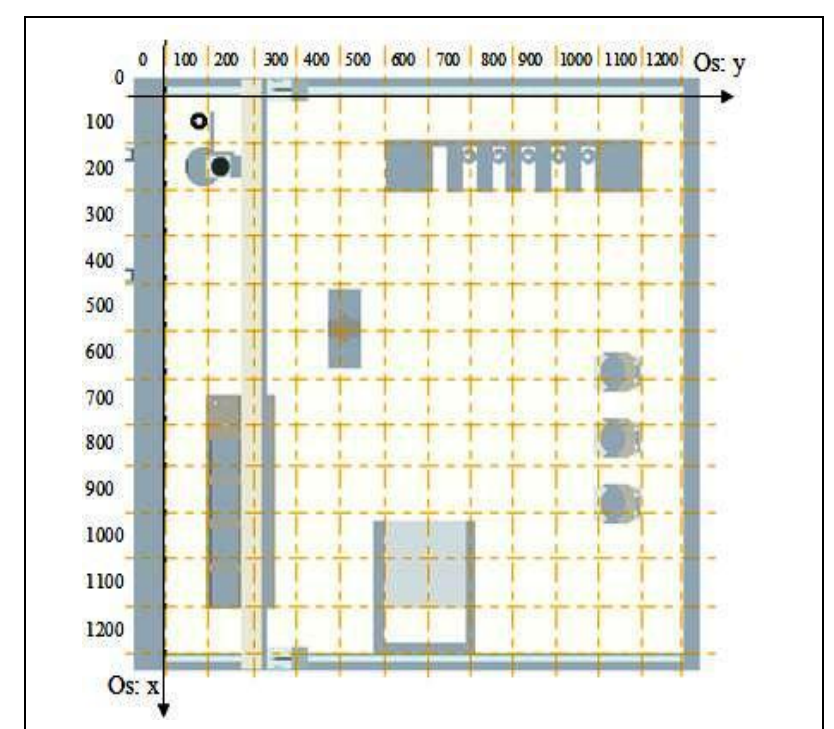

Fig. 5. workplace at the intelligent manufacturing cell - axis $\mathrm{X}, \mathrm{Y}, \mathrm{Z}$

\section{CONCLUSION}

During the design process of intelligent manufacturing and assembly cell and automated tool change was applied sequence diagram methodology.

This methodology was designed within sensorial systems of all subsystems and devices, which are situated at the workplace of manufacturing and assembly cell. Through sequence diagrams is possible to describe function and stays of this cell, which are needed by parts production and assembly at the intelligent system workplace.

This paper was realised by feasibility study: VEGA 1/0206/09 Intelligent assembly cell

\section{REFERENCES}

Kostal, P. \& Mudrikova, A. (2008). Material flow in flexible manufacturing and assembly. Academic Journal of Manufacturing Engineering, Supplement, Issue 1, September 2008, p. 185-191, ISSN 1583-7904

Majerik, J. \& Bajcik, S. (2008). CAD/CAM systems aid by computer. Strojárstvo, Vol. 12, No. 11, 2008, p. 108 - 109, ISSN 1335-2938

Mudriková, A. \& Charbulová, M. (2010). Material flow in flexible manufacturingcell. AMO Conference. - ISSN 13134264. - 10. International conference, 27 - 29 June 2010 AMO 10, 27 June - 01 July 2010 CEEPUS (2010), s. 1-9

Kusiak, A. (2006). Manufacturing and Service Applications. International Journal of Production Research, Vol. 44, No 18 pp16-18, 2006

Kusiak, A \& Salustri. (2007). Computatioonal Intelligence in Product Design Engineering, IEEE Transactions on Systems, Part C, Vol 37, NO5,2007. pp766-778

Katalinic, B. (2007). Collective Behaviors Interconnected Bionic Assembly System-Working Scenarios and Strategies , Chapter 58 In DAAAM International Scientific Book 2007, B.KATALINIČ(Ed.), Published by DAAAM International, ISBN 3-901509-60-7, Vienna Austria pp659-666

Katalinic, B. (2002). Design and Scheduling of , Next Generation of self-organising assembly systems. Chapter 31, In DAAAM International Scientific Book 2002, B. Katalinic (Ed.), pp.299-314, Published by DAAA International, ISBN 3-901509-60-7, Vienna, Austria 